\title{
FACTORS AFFECTING THE DECISION OF THE SELECTION OF KOREAN TOURISTS FOR A TOURIST DESTINATION: A STUDY IN CENTRAL VIETNAM
}

\author{
DONG HOANG NGUYEN ${ }^{1}$, HAI THE HOANG ${ }^{*}$, HAU NGOC LE $^{3} \&$ VINH-LONG TRAN-CHI ${ }^{4}$ \\ ${ }^{I}$ School of Hospitality and Tourism, Hue University, Vietnam \\ ${ }^{* 2}$ College of Education, University of Danang, Vietnam. \\ ${ }^{3}$ Vietravel Company, Danang Branch, Vietnam \\ ${ }^{4}$ Ho Chi Minh City University of Education, Vietnam
}

\begin{abstract}
Tourism has been one of the economy's rapidly developing sectors, contributing to particular domestic economic growth in recent years. This paper aims to examine the factors influencingthe destination choice decisions of Korean tourists in Central Vietnam. In Central Vietnam, the data were obtained from 203 Korean tourists (84 males and 119 females). They completed a 34-item questionnaire related to the factors affecting tourists' destination choice decisions. The findings of this research indicated that the destination choice decisions of Korean tourists were most affected b] destination characteristics, leisure, and relaxation, and financial. The findings of this study also provided several usef $W$ references, especially for the Central region and other Vietnamese regions. abs22spli\$sueijmpe

KEYWORDS: Destination Choice, Destination Decision, Factors, Korean Tourists \& Vietnam
\end{abstract}

Received: Jun 06, 2020; Accepted: Jun 26, 2020; Published: Aug 10, 2020; Paper Id.: IJMPERDJUN2020707

\section{INTRODUCTION}

Tourism is one of the most important sectors for development economics, and it can be regarded as the world's large service industries. Competition among states makes it desirable to comprehend why tourists choose one travel destination over another. Those studies into factors influencing the destination choice decisions of tourists were conducted all over the world decades ago(Chapin, 1974; Harrison-Hill, 2000; Keating \& Kriz, 2008; Sirakaya, McLellan, \& Uysal, 1996; Um \& Crompton, 1990; Uysal, 1998; Woodside \& Lysonski, 1989). An Activity Pattern Model on factors influences travels destination decisions including personal characteristics, roles, motivations, ways of thinking, availability of facilities and services, and quality of facilities and services (Chapin, 1974). A process model of decision-making and factors affecting destination selections and tourism services consists of five stages: identifying needs and wants of tourists, seeking out and assessing relevant information, travel decisions, preparing and experiencing the trip, evaluating trip satisfaction(Mathieson \& Wall, 1982)that the internal and external factors in each stage have certain impacts at different levels. The factors affect the choice of tourist destinations including demographic factors; motivations; perceptions of destinations; travel preferences; benefits sought; awareness of opportunities; images of destinations; cognitive distance; amount of leisure time; attitudes about destinations; amount of travel time; paid vacations; cultural similarities; past experiences; physical capacity; health and wellness; life span, and affiliations(Sirakaya et al., 1996; Uysal, 1998). A model of traveler leisure destination awareness and choice was proposed byWoodside and Lysonski (1989). They indicated that a traveler's destination choiceis the result of an awareness process that leads to favorite, special offer among different destinations. This favorite was governed by traveler destination awareness and some feelings. The destination 
choices also depend on the characteristics, motivations, traveler feelings being affected by marketing strategies, as well as the impressive from the original destination images, to clarify positive, neutral, or negative affective.

A pleasure travel destination choice framework was proposed(Um \& Crompton, 1990) regarding factors influencing the destination choicesof tourist,including external and internal inputs. External inputs can be seen as the sum of marketing communications and social interactions that can be divided into social stimuli, symbolic stimuli, and significative stimuli. Internal inputs derive from a potential tourist's sociopsychological that includes personal characteristics (sociodemographics, personality, lifestyle, and situational factors), values, motives, and attitudes. According to the research byUm and Crompton (1991), the measurement of attitude should be based on attitude towards the action of travelling to a particular destination, rather than the attitude towards the destination itself. A model of factors affecting destination choices that include objective and subjective factors(Harrison-Hill, 2000)focused on factors such as distance, travel time, cost of a trip, risks as well as information and attractiveness of the destinations. Specifically, destination choice was divided into three phases: review, commitment, and final destination choice. When tourists know about the destination, they may commit themselves to choose in the evoked set, unacceptable destinations in the inert set, or unpleasant and uninterested destinations in the inept set.TheMutinda and Mayaka (2012) research was based on a system adapted from the model of destination choice. The factors affect destination choices, including environmental and individual trait factors. Environmental factors arelifestyle, culture, family, sources of information, and destination features. In contrast, individual trait variables relate to personal characteristics, including personality, personal motivation, and past experiences.

In Vietnam, several studies have been conducted(Hoang, 2010; Nguyen, 2017; Nguyen, 2013; Nguyen, 2012); however, most of these studies focused only on the competitiveness of destination images of localities but did not explore the issues of the decision of tourist destination choices. In recent years several researchers have concentrated on research issues related to the tourists' destination decision making(Nguyen, 2015; Tran, 2015). The result showed that factors influencing the choice decision making of international visitors to ecotourism at Hoi An including ecotourism interests, the motivation of ecotourism, ecotourism attitudes, ecotourism experiences considered as internal factors (push factor), the availability and quality of the tour, tour prices, advertising, location of tour booking, reference groups be considered as external factors(Nguyen, 2015). A model of factors affects the decision of tourist destination choices(in the case of choosing Hoi An destination of Western European/North American tourists) including travel motivations, attitudes, destination experiences, destination images, reference groups, tour prices, media in tourism, and trip characteristics(Tran, 2015). The field of the study that explored and measured the factors affect the decision of tourists to choose Ho Chi Minh City destination, including tourism motivations, destination images, destination information. In particular, destination information influences tourism motivations and tourism motivations impact on destination images(Nguyen, 2016). A model of the relationship among factors affects attitudes, choice commitment, and tourists' destination loyalty. Destination choices are considered in two types of guests. The first, who have never been to the destination (committing to visit the destination).The second, who has been to the destination (intending to return and recommend to others). The results of the research showed that the factors affect Hanoi people's destination choices (in the case of choosing Hue/Danang destinations) including destination information, feelings toward a destination, internal forces, destination attitudes, and destination choices(Hoang, 2017).

Overall, there has been much research on factors affecting the choice of international tourist destinations, but there has not been any scientific research subject on Korean tourists' destination choices in Central Vietnam. In order to contribute 
to filling this gap, this research is conducted to explore the factors affecting the destination choices of Korean tourists in Central Vietnam. This aim of this research is to study and explore the factors that influence the destination choices for Korean tourists.

\section{METHODS}

Table 1: An overview of the survey participant

\begin{tabular}{|c|c|c|c|}
\hline & & $\mathbf{n}$ & $\%$ \\
\hline \multirow{2}{*}{ Gender } & Male & 84 & 41.4 \\
\hline & Female & 119 & 58.6 \\
\hline \multirow{5}{*}{ Age } & $<18$ & 8 & 3.9 \\
\hline & $19-30$ & 16 & 7.9 \\
\hline & $31-40$ & 25 & 12.3 \\
\hline & $41-50$ & 33 & 16.3 \\
\hline & $>50$ & 121 & 59.6 \\
\hline \multirow{4}{*}{ Education } & High school & 105 & 51.7 \\
\hline & $\begin{array}{l}\text { Vocational } \\
\text { school/College }\end{array}$ & 41 & 20.2 \\
\hline & University & 42 & 20.7 \\
\hline & Graduate degree & 15 & 7.4 \\
\hline \multirow{6}{*}{ Occupation } & Businessman & 78 & 38.4 \\
\hline & Civil servant & 14 & 6.9 \\
\hline & Student & 7 & 3.4 \\
\hline & Unskilled labourer & 22 & 10.8 \\
\hline & Retirement & 12 & 5.9 \\
\hline & Other & 70 & 34.5 \\
\hline \multirow{9}{*}{ Region } & Gyeonggi & 14 & 6.9 \\
\hline & Gangwon & 1 & \\
\hline & South Chungcheong & 3 & 1.5 \\
\hline & North Gyeongsang & 29 & 14.3 \\
\hline & South Gyeongsang & 16 & 7.9 \\
\hline & South Jeolla & 12 & 5.9 \\
\hline & Jeju & 3 & 1.5 \\
\hline & Seoul & 66 & 32.5 \\
\hline & Busan & 59 & 29.1 \\
\hline
\end{tabular}

Note: $\mathrm{n}$ - Number of participants; $\%$ - Percentage

The survey instrument was distributed to 225 Korean tourists, of which 220 surveys were returned, eliminating unsatisfactory answer sheets, the remaining sample of this study was 203 respondents who completed the survey instrument. The survey results in Table 1 indicate that there were more females (58.6\%) than males (41.4\%) among the 203 visitors who were surveyed. Of these, under 18 years of age (3.9\%), between 19 - 30 years of age (7.9\%), between 31 - 40 years of age (12.3\%), between 41 - 50 years of age (16.3\%), and over 50 years of age (59.6\%). Regarding the level of education, (51.7\%) of these visitors were in high school, in vocational school/college level (20.2\%), in university-level (20.7\%), and in graduate degree (7.4\%). Of the sample of 203 visitors surveyed (38.4\%) of these visitors were businessmen, civil servants (6.9\%), students (3.4\%), unskilled labourers (10.8\%), retired (5.9\%), and other jobs (34.5\%). Referring to the region of these visitors, Gyeonggi (6.9\%), Gangwon (0.5\%), South Chungcheong (1.5\%), North Gyeongsang (14.3\%), South Gyeongsang (7.9\%), South Jeolla (5.9\%), Jeju (1.5\%), Seoul (32.5\%), and Busan (29.1\%).

\section{RESULTS}


The results of Cronbach's Alpha coefficient of the scale on the factors affect to destination choices of Korean tourists in Central Vietnam including internal factors, external factors, and destination choice. As shown in Table 2, the Cronbach's Alpha coefficient of the scale "Internal factors" (17 items) were.926, "External factors" (17 items).942, and "Destination choices" (6 items).932. The Corrected Item - Total Correlation in this scale were all above 0.3. The results indicated that the scales used and the results of the research were reliable.

Table 2: Full scale Cronbach's Alpha coefficients

\begin{tabular}{|c|c|c|}
\hline Items & $\begin{array}{c}\text { Corrected Item - Total } \\
\text { Correlation }\end{array}$ & Cronbach's Alpha if Item Deleted \\
\hline \multicolumn{3}{|c|}{ Internal factors $(\mathrm{N}=17)$, Cronbach alpha $=.926$} \\
\hline C. 1 & .581 & .923 \\
\hline C.2 & .555 & .924 \\
\hline C.3 & .631 & .922 \\
\hline C. 4 & .494 & .926 \\
\hline C.5 & .562 & .924 \\
\hline C.6 & 607 & .922 \\
\hline C.24 & .493 & .926 \\
\hline C. 25 & .669 & .921 \\
\hline C.26 & .708 & .920 \\
\hline C. 27 & .764 & .919 \\
\hline C. 28 & .758 & .919 \\
\hline C.29 & .712 & .920 \\
\hline C. 30 & .643 & .921 \\
\hline C. 31 & 637 & .922 \\
\hline C.32 & .619 & .922 \\
\hline C.33 & .691 & .920 \\
\hline C.34 & 629 & .922 \\
\hline \multicolumn{3}{|c|}{ External factors $(\mathrm{N}=17)$, Cronbach alpha $=.942$} \\
\hline C.7 & .641 & .939 \\
\hline C.8 & .700 & .938 \\
\hline C.9 & .616 & .940 \\
\hline C. 10 & .710 & .938 \\
\hline C. 11 & .730 & .937 \\
\hline C.12 & .730 & .937 \\
\hline C.13 & .673 & .939 \\
\hline C.14 & .748 & .937 \\
\hline C.15 & .659 & .939 \\
\hline C.16 & .671 & .939 \\
\hline C. 17 & .440 & .944 \\
\hline C. 18 & .690 & .938 \\
\hline C. 19 & .748 & .937 \\
\hline C. 20 & .710 & .938 \\
\hline C. 21 & .710 & .938 \\
\hline C. 22 & .712 & .938 \\
\hline C. 23 & .688 & .938 \\
\hline \multicolumn{3}{|c|}{ Destination choice $(\mathrm{N}=6)$, Cronbach alpha $=.932$} \\
\hline C. 35 & .760 & .925 \\
\hline
\end{tabular}




\begin{tabular}{|l|l|l|}
\hline C. 36 & .775 & .923 \\
\hline C. 37 & .834 & .915 \\
\hline C. 38 & .823 & .917 \\
\hline C.39 & .828 & .917 \\
\hline C. 40 & .786 & .921 \\
\hline
\end{tabular}

We used correlation and regression analysis between the factors and the choice of tourist destinations to check whether the theoretical model was consistent with the data collected. The research model consists of 11 components: (1) knowledge and discovery, (2) leisure and relaxation, (3) culture and religion, (4) family and friends, (5) proud of the trip, (6) personal safety, (7) destination information, (8) destination characteristics, (9) financial, (10)travel arrangement, and (11) destination choice. In particular, ten variables $(1-10)$ were independent variables that were assumed to be the factors affecting the choice of Korean tourists' destination with the destination in Central Vietnam. The authors used the correlation method to assess the association and relationship between all variables. The regression analysis was performed to examine the amount of each variable, influencing the destination choices of Korean tourists. Statistical Package for the Social Sciences version 20 used for correlation and regression analysis.

The results of the correlation analysis (Table 3) show that the correlation coefficients between internal factors, external factors, and the destination choices of Korean tourists with a destination in Central Vietnam ( $\mathrm{r}$ ) =.229 .593, $\mathrm{p}<$ 0.01 indicated that the factors were positive correlation and statistically significant.

Table 3: Pearson's correlation coefficients between the factors

\begin{tabular}{|c|c|c|c|c|c|c|c|c|c|c|c|}
\hline & $\mathbf{F 1}$ & $\mathbf{F 2}$ & $\mathbf{F 3}$ & $\mathbf{F 4}$ & $\mathbf{F 5}$ & $\mathbf{F 6}$ & $\mathbf{F 7}$ & $\mathbf{F 8}$ & $\mathbf{F 9}$ & F10 & F11 \\
\hline F1 & 1 & & & & & & & & & & \\
\hline F2 & $.581^{* *}$ & 1 & & & & & & & & & \\
\hline F3 & $.417^{* *}$ & $.642^{* *}$ & 1 & & & & & & & & \\
\hline F4 & $.513^{* *}$ & $.696^{* *}$ & $.486^{* *}$ & 1 & & & & & & & \\
\hline F5 & $.474^{* *}$ & $.676^{* *}$ & $.579^{* *}$ & $.689^{* *}$ & 1 & & & & & & \\
\hline F6 & $.657^{* *}$ & $.473^{* *}$ & $.278^{* *}$ & $.294^{* *}$ & $.259^{* *}$ & 1 & & & & & \\
\hline F7 & $.579^{* *}$ & $.462^{* *}$ & $.287^{* *}$ & $.304^{* *}$ & $.319^{* *}$ & $.738^{* *}$ & 1 & & & & \\
\hline F8 & $.660^{* *}$ & $.732^{* *}$ & $.604^{* *}$ & $.577^{* *}$ & $.561^{* *}$ & $.599^{* *}$ & $.640^{* *}$ & 1 & & & \\
\hline F9 & $.795^{* *}$ & $.598^{* *}$ & $.326^{* *}$ & $.409^{* *}$ & $.448^{* *}$ & $.693^{* *}$ & $.643^{* *}$ & $.625^{* *}$ & 1 & & \\
\hline F10 & $.502^{* *}$ & $.577^{* *}$ & $.379^{* *}$ & $.374^{* *}$ & $.389^{* *}$ & $.652^{* *}$ & $.664^{* *}$ & $.688^{* *}$ & $.544^{* *}$ & 1 & \\
\hline F11 & $.581^{* *}$ & $.754^{* *}$ & $.536^{* *}$ & $.552^{* *}$ & $.593^{* *}$ & $.476^{* *}$ & $.438^{* *}$ & $.784^{* *}$ & $.606^{* *}$ & $.574^{* *}$ & 1 \\
\hline
\end{tabular}

Note: $* * \mathrm{p}<0.05$

The results show that the internal factors (destination motivation: knowledge and discovery, leisure and relaxation, culture and religion, family and friends, and proud of the trip) and the external factors (personal safety, destination information, destination characteristics, financial, andtravel arrangement) had a strong correlation with destination choices of Korean tourists in Central Vietnam. The results ensured conditions for future regression analyses to be performed.

According to the results of the correlation analysis, the authors continue to perform Multiple Regressions Analysis including ten independent variables in Multiple Regression Analysis as shown in Table 4 to validate the relationship and the effect of the factors on the destination choices of Korean tourists in Central Vietnamese.

Table 4: Regression analysis results 


\begin{tabular}{|c|c|c|c|c|c|c|}
\hline Independent variables & $\begin{array}{c}\mathbf{R} \\
\text { Square }\end{array}$ & $\begin{array}{c}\text { Adjusted } \\
\text { R } \\
\text { Square }\end{array}$ & $\mathbf{F}$ & $\begin{array}{c}\text { Beta } \\
\text { (B) }\end{array}$ & $\mathbf{t}$ & $\mathbf{p}$ \\
\hline Knowledge and discovery (F1) & \multirow{10}{*}{.715} & \multirow{10}{*}{.700} & \multirow{10}{*}{$48.114 * * *$} & -.022 & -.304 & .762 \\
\hline Leisure and relaxation (F2) & & & & .311 & 4.168 & .001 \\
\hline Culture and religion (F3) & & & & -.044 & -.782 & .435 \\
\hline Family and friends (F4) & & & & -.058 & -.946 & .345 \\
\hline Proud of the trip (F5) & & & & .115 & 1.888 & .060 \\
\hline Personal safety (F6) & & & & .006 & .093 & .926 \\
\hline Destination information (F7) & & & & -.209 & -3.229 & .001 \\
\hline Destination characteristics (F8) & & & & .537 & 7.183 & .001 \\
\hline Financial (F9) & & & & .183 & 2.455 & .015 \\
\hline Travel arrangement(F10) & & & & .065 & 1.058 & .291 \\
\hline
\end{tabular}

Note: $* * * \mathrm{p}<0.001$

The results of the regression $\mathrm{R}^{2}=.715$ show that the model's suitability was $71.5 \%$ or, in other words, $71.5 \%$ of the components' impact was being considered as to the destination choices of Korean tourists in Central Vietnam. The adjusted $\mathrm{R}^{2}$ indicates that the suitability of the model for the whole was more accurately reflected, $\mathrm{R}^{2}=.700(70.0 \%)$, which means the linear regression model between the destination choices of Korean tourists and ten components affecting Korean tourists' the destination choices.

The results of the ANOVA analysis show that the Sig =.001 $(<0.05)$ indicates that the regression model was consistent with the data collected and that the variables were statistically significant at 0.05 level. The value of $\mathrm{F}=48.114$ was used in order to check the hypothesis $\mathrm{H} 0$, which shows a significant linear relationship with $\mathrm{p}<0.05$. We can reject the hypothesis $\mathrm{H} 0$ that the angular coefficients of 10 components in the influencing factors are 0 . Thus the independent variables in the model were related to the dependent variables.

The analysis results of the coefficient regression model show that some components were the statistically significant level of 0.05 including leisure and relaxation (F2), destination information (F7), destination characteristics (F8), and financial (F9). However, destination information (F7) had negative regression values whilst the correlation analysis results were positive. That component would be rejected in this case(Falk \& Miller, 1992).Therefore, only a few components had a significant influence on the model and positively affected the destination choices of Korean tourists. The standardized values of regression of the independent variables in the model: destination characteristics (F8) were.537, leisure and relaxation (F2).311, and financial (F9).183. From the results of the regression analysis, we set up a standardized regression equation as follows:

$$
\mathrm{SLC}=.537 * \mathrm{~F} 8+.311 * \mathrm{~F} 2+.183 * \mathrm{~F} 9+.300
$$

The model clarified $70 \%$ the change of the destination choice variable due to the independent variables in the model that created. Remaining 30\% of the variables attributed to other variables outside the model. The model indicated that the independent variables positively influenced $95.0 \%$ of destination choices of Korean tourists level. Through the data shown in the regression equation, under the condition that the other remaining independent variables unchanged and then when evaluating destination characteristics (F8) variable increased by one unit, lead to the change of variable "destination choice" increased by.537 units; if leisure and relaxation (F2) increased by one unit, the destination choice raised by.311 units; if the variable of "financial" (F9) increased by one unit, the change of the variable "destination choice" went up by.183 units. 
The findings of standardized regression coefficients (Standardized Coefficients Beta) showed the importance of each independent variable to the dependent variable. Beta value (Table 4) indicates the level of influence between 10 independent and dependent variables. In particular, standardized regression coefficients of the "destination characteristics" affected $53.7 \%$ of destination choice, " leisure and relaxation" influencing $31.1 \%$ of destination choice, and "financial" affecting $18.3 \%$ to destination choice. The remaining variables in the model had low to no influence on tourists' destination choices.

Table 5: Summary of hypotheses and results

\begin{tabular}{|l|c|}
\hline \multicolumn{1}{|c|}{ Hypothesis } & Decision \\
\hline $\begin{array}{l}\text { H1: There is a positive impact between the factors of knowledge and discovery and tourists' } \\
\text { destination choice }(+)\end{array}$ & Rejected \\
\hline $\begin{array}{l}\text { H2: There is a positive impact between the factors of leisureand relaxation and tourists' destination } \\
\text { choice }(+) .\end{array}$ & Accepted \\
\hline $\begin{array}{l}\text { H3: There is a positive impact between the factors of culture and religion and tourists' destination } \\
\text { choice }(+) .\end{array}$ & Rejected \\
\hline $\begin{array}{l}\text { H4: There is a positive impact between the factors of family and friends and tourists' destination } \\
\text { choice }(+) .\end{array}$ & Rejected \\
\hline $\begin{array}{l}\text { H5: There is a positive impact between the factors of proud of the trip and tourists' destination choice } \\
(+) .\end{array}$ & Rejected \\
\hline $\begin{array}{l}\text { H6: There is a positive impact between the factors of personal safety and tourists' destination choice } \\
(+) .\end{array}$ & Rejected \\
\hline $\begin{array}{l}\text { H7: There is a positive impact between the factors of destination information and tourists' destination } \\
\text { choice and bearing the sign }(+) .\end{array}$ & Rejected \\
\hline $\begin{array}{l}\text { H8: There is a positive impact between the factors of destination characteristics and tourists' } \\
\text { destination choice }(+) .\end{array}$ & Accepted \\
\hline $\begin{array}{l}\text { H9: There is a positive impact between the factors of financial and tourists' destination choice and } \\
\text { bearing the sign }(+) .\end{array}$ & Accepted \\
\hline $\begin{array}{l}\text { H10: There is a positive impact between the factors of travel arrangement and tourists' destination } \\
\text { choice }(+) .\end{array}$ & Rejected \\
\hline
\end{tabular}

Through the data shown in Table 5, we saw that all of the hypothesis H2, H8, and H9 were accepted because the increase in these factors would lead to an increase in the level of affecting the destination choice of tourists. From the above analysis results, we can conclude that the theoretical model was partially appropriate with the research data and research hypotheses being accepted.

\section{DISCUSSIONS}

This research examined the factors that influence the destination choice decisions of Korean tourists in Central Vietnam. The main findings indicated that in general, the internal factors and the external factors had a strong correlation with the destination choices of Korean tourists in Central Vietnam. The destination characteristics, leisure and relaxation, and financial were found to be the most important factors affecting the destination choice decisions of Korean tourists. The remaining variables in the model had low to no influence on tourists' destination choices.

The destination choice decisions of Korean tourists are most strongly affected by destination characteristics, leisure and relaxation, and financial factors. The findings are consistent with the previous study for the choice of destination(Mutinda \& Mayaka, 2012). Moreover, the destination characteristics were found to be the most significant external factors that influence the choice of destination. The destination characteristics are a significant factor in the success and development of the tourist destination. Therefore, focusing on building the image of the destination characteristics is important. However, this finding is not consistent with prior researches that have concluded that the destination characteristics has a negligible 
effect on the destination choices of Western European/North American tourists(Tran, 2015).

In order to attract tourists choosing Vietnamese destination, there are several recommendations as below: Firstly, prices must be strictly regulated by tourism organizations such as tour prices, shopping, accommodation, tourism service, restaurants. Secondly, information about destinations should be invested and developed to help Korean tourists know more about the Vietnamese destination through tourism advertising and attractive promotional programmes. Thirdly, destination programs and activities should be developed to provide tourists with more diverse choices. Fourthly, many issues relating to pollution from the environment, traffic jams, pickpocket and robbery, stalking hawkers, must be controlled and improved. Eventually, the facilities of hotels, restaurants, resorts, and entertaining places need to be revamped to give Korean tourists a relaxed feeling.

The study has been taken from Korean tourists in Central Vietnam. The convenient random selection of participants greatly decreases this concern but does not fully resolve this shortcoming. The second limitation relates to the sampling and self-reported measurements. This could also lead to bias in the findings and was cross-sectional research that does not permit reliable results. Future studies are expected to carry out research with a comprehensive research model to take those limitations into account, making the results more accurate.

\section{CONCLUSIONS}

The objective of the research was to evaluate factors, motivation, needs and requirements affecting the destination choice decisions of Korean tourists in Central Vietnam. The researchers adopted a descriptive quantitative research design and applied descriptive analysis for the study. The research assesses the actual factors affecting the decision to travel for Korean tourists in Central Vietnam. The findings indicate that the Korean tourists' destination choices have the most influence on destination characteristics, leisure and relaxation, and financial.

The results of this study have helped to provide important recommendations and foundations for business organizations operating in the tourism sector in Central in particular and in Vietnam, in general, should take into account the critical roles of internal and external factors. Furthermore, the findings can be used as valuable information for destination marketers, and managers find the measures to enhance the factors that have a strong impact on tourists' destination choices to attract more tourists to Vietnam.

\section{REFERENCES}

1. Chapin, F. S. (1974). Human Activity Patterns in the City: Things People Do in Time and in Space (Wiley series in urban research). New Jersey, United States: John Wiley \& Sons Inc.

2. Chand, M. O. H. I. N. D. E. R., and D. A. H. I. Y. A. Ashish. "The impact of service quality on tourist satisfaction and loyalty in Indian tour operation industry." International Journal of Sales \& Marketing Management Research and Development (IJSMMRD) 4.5 (2014): 1-14.

3. Falk, R. F., \& Miller, N. B. (1992). A primer for soft modeling. Ohio, United States: University of Akron Press.

4. Harrison-Hill, T. (2000). Investigating cognitive distance and long-haul destinations. Tourism Analysis, 5(2-3), 83-90.

5. Hoang, T. D. T. (2010). Nghiên cúu các chỉ bảo phát triển du lịch bền vũng tại các điểm tham quan du lịch thuộc quần thể di tích Hué (Việt Nam) [Study the indicators for sustainable tourism development at tourist attractions belonging to Hue Monuments Complex (Vietnam)]. Tạp chí Khoa học, Đại học Huê, 62, 127-140. 
6. Hoang, T. T. H. (2017). Các yếu tố ảnh hương tới sụ lựa chọn điểm đến của người dân Hà Nội: nghiên cứu truờng hợp điểm đến Huế, Đà Nã̃ng [Factors affecting destination choice of Hanoi residents: the case of Hue and Danang]. Doctoral dissertation, National Economics University, Hanoi, Vietnam.

7. Isaac, A. O., and A. O. Oyelade. "Copyright@ 2019 by Academic Publishing House Researcher sro Published in the Slovak Republic Tourism Education Studies and Practice." (2019).

8. Keating, B., \& Kriz, A. (2008). Outbound tourism from China: Literature review and research agenda. Journal of Hospitality and Tourism management, 15(1), 32-41.

9. Mathieson, A., \& Wall, G. (1982). Tourism, economic, physical and social impacts. London, United Kingdom: Longman.

10. Mutinda, R., \& Mayaka, M. (2012). Application of destination choice model: Factors influencing domestic tourists destination choice among residents of Nairobi, Kenya. Tourism Management, 33(6), 1593-1597.

11. Nguyen, B. T. T. (2017). Nghiên cứu hình ảnh điểm đến du lịch Huế [Measuring tourist destination images of Hue]. Master's thesis, College of Economics, Hue University, Hue, Vietnam.

12. Nguyen, T. B. T. (2013). Đo lương hình ảnh điểm đến của du khách quốc tế-Trưòng hợp thành phố Đà Nẵng [Measurement of measuring international tourist destination images - Case of Danang City]. Doctoral dissertation, University of Danang, Danang, Vietnam.

13. Nguyen, T. K. L. (2015). Nghiên cưu các nhân tố ảnh huởng đến quyết định lụa chọn sản phẩm tour du lịch sinh thái của du khách quốc tế tại Hội An [Factors affecting the choice of ecotourism products by international visitors in Hoi An]. Doctoral dissertation, University of Danang, Danang, Vietnam.

14. Nguyen, T. T. V. (2012). Nghiên cứu năng lục cạnh tranh điểm đến du lịch Đà Nã̃ng [Research competitiveness of tourism destinations in Danang]. Tạp chí khoa học, trừng Đại học Đông A, 8, 5-12.

15. Nguyen, X. H. (2016). Các yếu tố ảnh hưởng đến quyết định lựa chọn điểm đến của khách du lịch: Truờng hợp điểm đến TP. Hồ Chi Minh [Factors affecting tourists' decision to choose Ho Chi Minh City as their destination]. Journal of Asian Business and Economic Studies, 27(9), 53-72.

16. Olukole, Titilayo O. "Geographical Information System (GIS) and Tourism: The Prediction of archaeological sites in IjaiyeOrile, Southwestern Nigeria." NyameAkuma Bulletin (2007): 69-74.

17. Sirakaya, E., McLellan, R. W., \& Uysal, M. (1996). Modeling vacation destination decisions: A behavioral approach. Journal of Travel \& Tourism Marketing, 5(1-2), 57-75.

18. SHRESTHA, ROSHAN. A Study on Effectiveness of Advertisement in Nepal Tourism Board on Tourism Sector.Diss. Office of the Dean Faculty of Management Tribhuvan University, 2011.

19. Tran, T. K. T. (2015). Nghiên cưu các yếu tố ảnh hưởng đến quyết định lựa chọn điểm đến du lịch của du khách-Truờng hơp lựa chọn điểm đến Hội An của khách du lịch Tây Âu-Bắc Mỹ [Factors influencing tourists' decision to choose a tourist destination: The case of choosing Hoi An destination for Western European-North American tourists]. Master's thesis, University of Danang, Danang, Vietnam.

20. Um, S., \& Crompton, J. L. (1990). Attitude determinants in tourism destination choice. Annals of tourism research, 17(3), 432448.

21. Um, S., \& Crompton, J. L. (1991). Development of pleasure travel attitude dimensions. Annals of Tourism Research, 18(3), 500504.

22. Uysal, M. (1998). The determinants of tourism demand The economic geography of the tourist industry: A supply-side analysis 
(pp. 79-95). London, United Kingdom: Routledge.

23. Woodside, A. G., \& Lysonski, S. (1989). A general model of traveler destination choice. Journal of Travel Research, 27(4), 814. 